\title{
Control of Bacterial Seedling Rot and Seedling Blight of Rice by Bacteriophage
}

Naoto Adachi and Shoichi Tsukamoto, Ishikawa Agricultural Research Center, 295-1 Saida, Kanazawa, Ishikawa 920-3198, Japan; and Yasuhiro Inoue and Koji Azegami, National Agricultural Research Center, 3-1-1 Kannondai, Tsukuba, Ibaraki 305-8666, Japan

\begin{abstract}
Adachi, N., Tsukamoto, S., Inoue, Y., and Azegami, K. 2012. Control of bacterial seedling rot and seedling blight of rice by bacteriophage. Plant Dis. 96:1033-1036.

In Japan, rice seed are immersed in pesticide solutions to prevent seedborne diseases that attack greenhouse seedlings. However, disposal of large quantities of waste pesticide solutions after treatment is costly. As an alternative treatment, bacteriophages (phages) that are highly specific to the target bacteria are considered as potential biocontrol agents. Here, we isolated three phage strains that lyse Burkholderia glumae and B. plantarii, the causative pathogens of seedling rot and seedling blight, respectively. Two phages could lyse both bacteria and clearly suppress these diseases. One of these phages (BGPP-Ar) suppressed these diseases more effectively than existing pesticides: the ratio of

seedlings exhibiting disease to the total number of seedlings examined after treatment with BGPP-Ar $1.0 \times 10^{8}$ plaque-forming units $(\mathrm{PFU}) / \mathrm{ml}$ was 0.0 for seedling rot and 2.0 for seedling blight; after treatment with ipconazole/copper (II) hydroxide, the ratios were 14.3 and 15.0, respectively. BGPP-Ar was highly effective in suppressing seedling rot of rice, even at the low concentration of $1.0 \times 10^{5} \mathrm{PFU} / \mathrm{ml}$. The best phage treatment effect for sterilizing seed is achieved indoors to avoid phage inactivation by UV irradiation. Treatment effect was demonstrated on seed infected with pathogens. Therefore, we consider that phage treatment was effective in this study.
\end{abstract}

In recent years, Japanese consumers have become increasingly interested in environmental conservation-oriented agriculture and are becoming more strongly concerned about food safety. In addition, there is now a demand for environmentally friendly techniques of plant disease control that do not rely on the chemical pesticides that have been the mainstay of modern agriculture. In the cultivation of rice, seed are germinated in greenhouses and the seedlings are transplanted to the fields. However, effective control of seedborne bacterial and fungal diseases, which break out repeatedly in the warm, humid greenhouse environment, is required because occurrence of diseases can lead to a shortage of seedlings for planting. The current control measure is to sterilize seed with chemical pesticides, which results in the production of enormous amounts of waste liquid containing pesticides. Because growers are prohibited from discharging this waste liquid without treatment to remove pesticide constituents for environmental protection reasons, methods such as treatment with activated charcoal are required. These processes can carry considerable costs.

Under such circumstances, two control measures against seedborne diseases of rice have been developed and put into practical use: hot water treatment of seed (18-20) and the use of nonpathogenic fungi (microbial pesticides) (11). However, sterilizing seed in hot water sometimes reduces the germination rate, depending on the conditions. Microbial pesticides do not directly kill bacteria but are believed to keep the outbreak of disease in check by suppressing the reproduction of pathogenic bacteria through nutrient competition. Thus, microbial pesticides are likely to be less effective when seed are highly infested.

Our objective was to develop a method to control two seedborne bacterial diseases in rice: seedling rot (16) caused by Burkholderia glumae (17) and seedling blight (4) caused by B. plantarii (17). We examined the use of bacteriophages (phages) as a method that has little impact on the environment and that has been shown to be as effective as chemical pesticides in other applications. Previous research has identified phages that control diseases such as tomato

Corresponding author: Naoto Adachi, E-mail: n-adc@pref.ishikawa.lg.jp

Accepted for publication 13 February 2012.

http://dx.doi.org/10.1094/PDIS-03-11-0232-RE

(C) 2012 The American Phytopathological Society bacterial spot $(6,8,13)$, bacterial blight of geranium (7), Xanthomonas leaf blight of onion (12), and citrus bacterial spot (5).

Here, we isolated naturally occurring phages and investigated their ability to suppress the disease-causing bacteria under study in the germination of rice seed.

\section{Materials and Methods}

Bacterial strains and culture. The bacterial strains used in this study were B. glumae MAFF 106715 and MAFF 106717 and $B$. plantarii MAFF 301723. Each strain was cultured for 2 days at $28^{\circ} \mathrm{C}$ on PPGA medium (infusion from $200.0 \mathrm{~g}$ of potato, $3.0 \mathrm{~g}$ of disodium hydrogen phosphate 12 -water, $0.5 \mathrm{~g}$ of potassium phosphate dibasic, $5.0 \mathrm{~g}$ of glucose, $5.0 \mathrm{~g}$ of peptone, $3.0 \mathrm{~g}$ of sodium chloride, and $15.0 \mathrm{~g}$ of agar, $\mathrm{pH} 7.0$ ). The cultured bacteria were suspended in sterile distilled water, and the suspensions were adjusted to approximately $1 \times 10^{8} \mathrm{CFU} / \mathrm{ml}$ for use in experiments.

Phage isolation and multiplication. Water was sampled from rivers, irrigation ditches, and puddles around and in paddy fields in Kanazawa City, Ishikawa Prefecture, and Tsukuba City, Ibaraki Prefecture, in order to identify naturally occurring phages. The water samples were passed through 5- and $0.2-\mu \mathrm{m}$ filters to remove as many impurities and microorganisms as possible. Filtrate $(1 \mathrm{ml})$ and a suspension of the indicator bacterial strain $(1 \mathrm{ml})$ were mixed with $10 \mathrm{ml}$ of liquid PSA medium (infusion from $200.0 \mathrm{~g}$ of potato, $2.0 \mathrm{~g}$ of sodium phosphate dibasic 12 -water, $0.5 \mathrm{~g}$ of calcium nitrate 4-water, $15.0 \mathrm{~g}$ of sucrose, $5.0 \mathrm{~g}$ of peptone, and $10.0 \mathrm{~g}$ of agar, $\mathrm{pH} 7.0$ ) at $55^{\circ} \mathrm{C}$, poured into a 9 -cm-diameter dish, and allowed to solidify. The mixture was incubated at $28^{\circ} \mathrm{C}$ and checked for plaques after $16 \mathrm{~h}$. Individual plaques were collected and suspended in sterile distilled water, dilution steps were prepared, and cultures were replated using the same method to produce plaques again. The process was repeated three times, and the final individual plaques were taken to be pure phage cultures.

From a single pure plaque, 500 or more plaques per dish were formed. Phage suspension was prepared by adding $10 \mathrm{ml}$ of sterile distilled water to the plate, collecting the liquid after $1 \mathrm{~h}$, and filtering it twice through a $0.2-\mu \mathrm{m}$ filter to remove bacteria. The concentration of phages in each phage suspension was evaluated by plaque assay, adjusted to the desired concentration, and used in the experiment.

Phage typing of bacterial strains. Lytic spectra of the isolated phages were examined in the following manner. Bacterial suspension $(1 \mathrm{ml})$ was mixed with $10 \mathrm{ml}$ of liquid PSA medium at $55^{\circ} \mathrm{C}$, 
poured into a 9-cm-diameter dish, and allowed to solidify. Each phage suspension was adjusted to $1 \times 10^{8}$ plaque-forming units $(\mathrm{PFU}) / \mathrm{ml}$, and $2 \mu \mathrm{l}$ of the suspension was applied to the plate. The plate was incubated at $28^{\circ} \mathrm{C}$ and plaque formation was examined after $16 \mathrm{~h}$.

Infested seed. The rice seed ('Koshihikari') used in this study were obtained from the Ishikawa Agricultural Research Center. The inocula sources were B. glumae MAFF 106715 and MAFF 106717 and $B$. plantarii MAFF 301723. Infested seed were prepared by immersing seed in each bacterial suspension, placing them in a vacuum desiccator connected to an aspirator for $1 \mathrm{~h}$, and then air drying. Because the virulence of the pathogens was too strong, the seed were blended with noninoculated seed to reproduce disease symptoms occurring in greenhouses, which is in accordance with the efficacy evaluation method for agrochemicals.

Small-scale trials. Healthy seed (10 g), free from the pathogens, were mixed with $10 \mathrm{~B}$. glumae-infested seeds or $2 \mathrm{~B}$. plantariiinfested seeds and used as infested seed in the experiments.

Medium-scale trials. Healthy seed $(1 \mathrm{~kg})$ were mixed with $85 \mathrm{~g}$ of B. glumae-infested seed or $6 \mathrm{~g}$ of B. plantarii-infested seed.

Cultivation of rice plants. Small-scale trials. Infested seed were immersed in $30 \mathrm{ml}$ of sterile distilled water at approximately $15^{\circ} \mathrm{C}$ for 6 days. The immersion water was replaced with sterile distilled water after 3 days according to a conventional method and again after 6 days. Germination was induced by incubating the seed at $30^{\circ} \mathrm{C}$ for $24 \mathrm{~h}$. Plastic containers $(10$ by $15 \mathrm{~cm}$ ) were filled

Table 1. Bacterial strains and sensitivities to tested phages

\begin{tabular}{|c|c|c|c|}
\hline \multirow[b]{2}{*}{ Strain $^{z}$} & \multicolumn{3}{|c|}{ Phage sensitivity ${ }^{y}$} \\
\hline & BGPP-Ar & BGPP-Sa & BPP-Ya \\
\hline \multicolumn{4}{|c|}{ Burkholderia glumae } \\
\hline MAFF 106619 & - & - & - \\
\hline MAFF 106666 & + & + & - \\
\hline MAFF 106713 & - & - & - \\
\hline MAFF 106714 & - & - & - \\
\hline MAFF 106715 & + & + & - \\
\hline MAFF 106716 & + & + & - \\
\hline MAFF 106717 & - & - & - \\
\hline MAFF 106718 & - & - & - \\
\hline MAFF 106719 & + & + & - \\
\hline MAFF 106720 & + & + & - \\
\hline MAFF 106734 & + & + & - \\
\hline MAFF 106735 & + & + & - \\
\hline \multicolumn{4}{|l|}{ B. plantarii } \\
\hline MAFF 106672 & + & + & + \\
\hline MAFF 106673 & + & + & + \\
\hline MAFF 106676 & + & + & + \\
\hline MAFF 106677 & + & + & + \\
\hline MAFF 106680 & + & + & + \\
\hline MAFF 106681 & + & + & + \\
\hline MAFF 106682 & + & + & + \\
\hline MAFF 106683 & + & - & + \\
\hline MAFF 106688 & + & + & + \\
\hline MAFF 106721 & + & - & + \\
\hline MAFF 106722 & + & - & + \\
\hline MAFF 106723 & + & + & + \\
\hline MAFF 106724 & + & + & + \\
\hline MAFF 106725 & + & - & + \\
\hline MAFF 106726 & - & - & + \\
\hline MAFF 106727 & + & + & - \\
\hline MAFF 106728 & + & + & - \\
\hline MAFF 106729 & + & - & + \\
\hline MAFF 106730 & + & - & + \\
\hline MAFF 106731 & + & + & + \\
\hline MAFF 106732 & + & + & + \\
\hline MAFF 106733 & + & - & + \\
\hline ADC 0803 & + & - & - \\
\hline MAFF $301723^{\mathrm{T}}$ & + & + & + \\
\hline
\end{tabular}

y Symbols: $+=$ positive sensitivity, bacterial strain is infected by the phage, and $-=$ negative sensitivity, bacterial strain is not infected by the phage.

${ }^{\mathrm{z}} \mathrm{T}=$ type strain. with $100 \mathrm{ml}$ of vermiculite followed by $200 \mathrm{ml}$ of granulated seedling soil, and irrigated with $100 \mathrm{ml}$ of sterile distilled water. The germinated seed were sown and covered with an additional $100 \mathrm{ml}$ of seedling soil. The seed were irrigated with $50 \mathrm{ml}$ of sterile distilled water and kept in the dark for 3 days at $30^{\circ} \mathrm{C}$ to facilitate the emergence of seedlings. After emergence, the seedlings were grown for 4 days with a daily cycle of $16 \mathrm{~h}$ at $30^{\circ} \mathrm{C}$ under light and $8 \mathrm{~h}$ at $15^{\circ} \mathrm{C}$ in the dark.

Medium-scale trials. Approximately $1 \mathrm{~kg}$ of contaminated seed were placed in a mesh bag and soaked in tap water under the same conditions as above. Germination was induced by circulating tap water heated to $30^{\circ} \mathrm{C}$ using an $\mathrm{FH}-100 \mathrm{~N}$ circulation germinator (Tiger Kawashima, Ibaraki, Japan), which is popular in some areas of Japan. The germinated seed were sown at a density of $200 \mathrm{~g}$ preimmersion dry weight of seed to each nursery box (30 by 60 $\mathrm{cm})$ filled with seedling soil, and covered with soil. Seed were then cultivated for 2 weeks in a greenhouse.

Chemical or phage treatments. The chemical pesticide used was ipconazole/copper (II) hydroxide wettable powder (Kumiai Chemical Industry, Tokyo). The microbial pesticide was Trichoderma atroviride SKT-1 wettable powder (Kumiai Chemical Industry). Treatment was carried out according to the method recommended by the manufacturer. For ipconazole/copper (II) hydroxide wettable powder, undiluted solution was adjusted to $0.5 \%$ ( $\mathrm{vol} / \mathrm{vol})$ with sterile distilled water, and seed were immersed in this solution in place of sterile distilled water on the first day of soaking. The treatment was carried out at approximately $15^{\circ} \mathrm{C}$ for $24 \mathrm{~h}$, after which the pesticide solution was discarded and the immersion was continued with sterile distilled water. For microbial pesticide, the powder was made up to a $0.5 \%$ (wt/vol) solution and used in place of distilled water when germination was induced, and seed were treated at $30^{\circ} \mathrm{C}$.

The phage suspensions were used in place of distilled water or tap water when germination was induced to treat the seed at $30^{\circ} \mathrm{C}$. Small-scale trials were carried out with three replicates and medium-scale trials were carried out with five replicates.

Investigation of disease-suppression effect. Small-scale trials. To assess each of the three phages for seedling rot and blight suppression effects, we first used high-concentration phage suspensions to treat the seed, together with forced germination. As a comparison, seed were separately treated with an existing agrochemical or microbial pesticide. We then investigated the disease-suppression effect of phage BGPP-Ar using a wide range of suspension concentrations; phages may exhibit a disease-suppression effect even when used at low concentrations because of their capability for proliferation following infection of bacteria.

Medium-scale trials. We investigated the disease-suppression effects under use with actual germinator equipment and seedling nursery boxes.

Determination of disease prevalence and statistical analysis. Small-scale trials. We counted the seedlings exhibiting rot or blight and calculated the ratio of each to the total number of seedlings examined.

Medium-scale trials. We visually examined the seedlings in the nursery box and calculated the ratio of the area occupied by diseased seedlings to the total box area, because diseased seedlings are often found clustered in part of the nursery box.

Statistical analysis was performed with JMP8 software (SAS Institute Japan, Tokyo) using Tukey's multiple range test (honestly significant difference) with arcsine transformation of the data on the diseased seedling number or area ratio. The level of statistical significance was set at $3 \%$.

\section{Results}

Isolated phages and their host ranges. Phages BPP-Ya and BGPP-Ar, lytic to $B$. plantarii MAFF 301723, were isolated in October 2002 from river water and in November 2007 from puddle water in paddy fields in Tsukuba City, Ibaraki Prefecture. Phage BGPP-Sa, lytic to B. glumae MAFF 106715, was isolated in November 2004 from river water in Kanazawa City, Ishikawa Prefec- 
ture. BPP-Ya plaques were 3 to $4 \mathrm{~mm}$ in diameter and BGPP-Ar and BGPP-Sa plaques were approximately $1 \mathrm{~mm}$.

Examination of the lytic spectra showed that BPP-Ya was lytic only to B. plantarii, while BGPP-Ar and BGPP-Sa were lytic to both $B$. glumae and B. plantarii. Some B. glumae strains were not lysed by any of the phages (Table 1 ).

Suppression of the diseases by phages. One hundred seedlings were randomly collected from each test section to evaluate the effects of the phages on disease incidence. When the rice seed were treated with BGPP-Ar phage suspension $\left(1 \times 10^{8} \mathrm{PFU} / \mathrm{ml}\right)$ at the time of germination induction, the incidence of both diseases caused by MAFF 106715 and MAFF 301723 was completely suppressed (Table 2). When the seed were similarly treated with BGPP-Sa, the incidence was also suppressed. The effectiveness of BGPP-Ar and BGPP-Sa, which are lytic to both pathogens, in suppressing both diseases was equal to or greater than that of existing chemical or microbial pesticides. On the other hand, BPP-Ya, which is lytic only to MAFF 301723, effectively suppressed only bacterial seedling blight.

None of the phages were lytic to B. glumae MAFF 106717, and their suspensions did not suppress the disease caused by it (Table 2).

BGPP-Ar was highly effective in suppressing seedling rot of rice even at the low concentration of $1.0 \times 10^{5} \mathrm{PFU} / \mathrm{ml}$, with no disease at any concentration (Table 3). However, it was less effective in suppressing seedling blight at the low concentration of $1.0 \times 10^{6}$ PFU/ml. Thus, to achieve practical suppression of both diseases, phage concentration needs to be $1.0 \times 10^{7} \mathrm{PFU} / \mathrm{ml}$ or higher.

In order to best replicate the method used in an actual rice nursery, medium-scale trials were carried out using a circulation germinator, and the percent area of diseased seedlings per box was determined. BGPP-Ar was highly effective in suppressing both diseases (Table 4). It suppressed seedling blight even at $1.0 \times 10^{5}$ $\mathrm{PFU} / \mathrm{ml}$ and seedling rot at $1.0 \times 10^{3} \mathrm{PFU} / \mathrm{ml}$. Although the incidence of seedling rot in the untreated seed boxes was quite low, it is notable that, whereas the rot incidence was apparently reduced in seedlings from seed treated with ipconazole/copper (II) hydroxide wettable powder, no rot was found in seed germinated after treatment with the phage suspension.

\section{Discussion}

Our objective was to develop an environmentally friendly technique to control bacterial seedling rot and seedling blight of rice through seed sterilization having an efficacy equivalent to that of chemical pesticides. Phages are highly specific to the target bacteria and considered to be potential biocontrol agents; therefore, we investigated their use for this purpose.

No phages lytic to $B$. plantarii have been reported. Although phages lytic to $B$. glumae have been reported (9), these are not available today. Therefore, we attempted to isolate phages lytic to these pathogens. Because the phages are obligate parasites to their host bacteria and have mobility in water, we examined water from rivers, irrigation ditches, and puddles around and in paddy fields in areas of rice cultivation. As a result, we isolated three phage strains: BGPP-Ar, BGPP-Sa, and BPP-Ya. The former two could lyse both B. glumae and B. plantarii and, remarkably, suppressed these diseases. The host specificity of a phage is extremely strict, and several different phagovars are known to exist even within a bacterial species. Thus, to control a bacterial disease, multiple phages generally need to be collected and applied so that all phagovars belonging to that species are lysed. However, BGPP-Ar and BGPP-Sa can lyse the two species of pathogenic bacteria studied. Because both diseases caused by these bacterial strains are seedborne and occur in similar conditions, they could be controlled simultaneously using a single phage. In the current disease control trials, although BGPP-Ar and BGPP-Sa suppressed the diseases caused by specific bacterial strains, they were not lytic to every $B$. glumae and $B$. plantarii strain. Although BPP-Ya could not lyse $B$. glumae, it could lyse most $B$. plantarii phagovars isolated in Japan (15), including those which BGPP-Ar and BGPP-Sa could not. Therefore, BPP-Ya is expected to have applications as a phage supplementing BGPP-Ar and BGPP-Sa.

All three phages were isolated from October to November, when rainy days become relatively frequent with the end of summer. In addition to these phages, a number of other $B$. glumae and $B$. plantarii phages have been isolated (1), and many of these were also isolated from September to November. This result suggests that the phages are very labile if the host bacteria are not present in the environment, and that they are likely to be control agents with little environmental impact.

In order to develop a control method for seedling diseases by phages, several issues must be resolved. First, no disease suppression effect will be achieved if the combination of phages is insensitive to the target bacterial strain. In fact, some bacteria phagovars were not lysed by any of the phages used in this study. It is very difficult to ascertain beforehand which phagovars have infected rice seed. Consequently, various phages lytic to a wide range of phagovars that are likely to be present are needed. Second, treatment with phages will foster the appearance of many phage-resistant strains (2). Resolving this issue will require preliminary preparations such as the development of new host range mutants (10).

Table 3. Effects of various phage concentrations on the incidence of seedling rot caused by phage-sensitive Burkholderia glumae MAFF 106715 and seedling blight by phage-sensitive $B$. plantarii MAFF 301723 in smallscale trials

\begin{tabular}{lcc}
\hline \multirow{2}{*}{$\begin{array}{l}\text { Treatment, } \\
\text { concentration }^{\mathbf{z}}\end{array}$} & \multicolumn{2}{c}{ Mean percentage of diseased seedlings ${ }^{\mathbf{y}}$} \\
\cline { 2 - 3 } & $\begin{array}{c}\text { B. } \text { glumae } \\
\text { (MAFF 106715) }\end{array}$ & \begin{tabular}{c} 
B. plantarii $^{\text {(MAFF 301723) }}$ \\
\hline $\mathrm{BGPP}-\mathrm{Ar}$
\end{tabular} \\
$1.0 \times 10^{8} \mathrm{PFU} / \mathrm{ml}$ & $0.0 \mathrm{a}$ & $\mathrm{NT}$ \\
$1.0 \times 10^{7} \mathrm{PFU} / \mathrm{ml}$ & $0.0 \mathrm{a}$ & $7.0 \mathrm{a}$ \\
$1.0 \times 10^{6} \mathrm{PFU} / \mathrm{ml}$ & $0.0 \mathrm{a}$ & $32.7 \mathrm{~b}$ \\
$1.0 \times 10^{5} \mathrm{PFU} / \mathrm{ml}$ & $0.0 \mathrm{a}$ & $\mathrm{NT}$ \\
None & $91.0 \mathrm{~b}$ & $100.0 \mathrm{c}$ \\
- &
\end{tabular}

${ }^{\mathrm{y}}$ Means followed by the same letter within a column are not significantly different by Tukey's multiple range test, $P=0.03 ; \mathrm{NT}=$ not tested.

${ }^{z}$ Phage concentration. $\mathrm{PFU}=$ plaque-forming units.

Table 2. Effects of phages and pesticides on the incidence of diseases caused by phage-sensitive and -insensitive bacteria in small-scale trials

\begin{tabular}{lccc}
\hline & \multicolumn{3}{c}{ Mean percentage of diseased seedlings $^{\mathbf{y}}$} \\
\cline { 2 - 4 } Treatment $^{\mathbf{z}}$ & \multicolumn{2}{c}{ Burkholderia glumae $^{\text {B. plantarii }}$} & MAFF 301723 \\
\cline { 2 - 3 } \cline { 2 - 3 } BGPP-Ar $\left(1.0 \times 10^{8} \mathrm{PFU} / \mathrm{ml}\right)$ & MAFF 106715 & MAFF 106717 & $2.0 \mathrm{a}$ \\
BGPP-Sa $\left(1.0 \times 10^{8} \mathrm{PFU} / \mathrm{ml}\right)$ & $0.0 \mathrm{a}$ & $87.3 \mathrm{a}$ & $3.3 \mathrm{a}$ \\
BPP-Ya $\left(1.0 \times 10^{8} \mathrm{PFU} / \mathrm{ml}\right)$ & $1.3 \mathrm{ab}$ & $84.3 \mathrm{a}$ & $6.3 \mathrm{a}$ \\
Trichoderma atroviride SKT-1 & $22.7 \mathrm{bc}$ & $100.0 \mathrm{a}$ & $3.0 \mathrm{a}$ \\
Ipconazole/copper (II) hydroxide & $9.0 \mathrm{ab}$ & NT & $15.0 \mathrm{a}$ \\
None & $14.3 \mathrm{abc}$ & $32.7 \mathrm{a}$ & $75.0 \mathrm{~b}$ \\
\hline
\end{tabular}

\footnotetext{
${ }^{y}$ Means followed by the same letter within a column are not significantly different by Tukey's multiple range test, $P=0.03$; NT $=$ not tested.
}

${ }^{\mathrm{z}} \mathrm{PFU}=$ plaque-forming units. 
Table 4. Effect of phages and pesticide on the incidence of the diseases caused by phage-sensitive bacteria in medium-scale trials

\begin{tabular}{lcc}
\hline & \multicolumn{2}{c}{ Mean percentage of diseased seedling area $^{\mathbf{y}}$} \\
\cline { 2 - 3 } Treatment $^{\mathbf{z}}$ & Burkholderia & glumae (MAFF 106715) \\
\hline BGPP-Ar $\left(1.0 \times 10^{8} \mathrm{PFU} / \mathrm{ml}\right)$ & $\mathrm{NT}$ & $0.0 \mathrm{a}$ \\
$\mathrm{BGPP}-\mathrm{Ar}\left(1.0 \times 10^{5} \mathrm{PFU} / \mathrm{ml}\right)$ & $0.0 \mathrm{a}$ & $0.0 \mathrm{a}$ \\
$\mathrm{BGPP}-\mathrm{Ar}\left(1.0 \times 10^{3} \mathrm{PFU} / \mathrm{ml}\right)$ & $0.0 \mathrm{a}$ & $\mathrm{NT}$ \\
Ipconazole/copper (II) hydroxide & $2.0 \mathrm{~b}$ & $0.0 \mathrm{a}$ \\
None & $8.0 \mathrm{~b}$ & $82.0 \mathrm{~b}$ \\
\hline
\end{tabular}

${ }^{y}$ Means followed by the same letter within a column are not significantly different by Tukey's multiple range test, $P=0.03$; NT $=$ not tested.

${ }^{\mathrm{z}} \mathrm{PFU}=$ plaque-forming units.

In spite of these issues, sterilizing seed by phage treatment has the advantage that the phages do not need to be scattered in the fields, because the opportunity for the phage to make contact with the pathogens is considerably higher in the germination immersions than in the fields. In tomato bacterial spot caused by Xanthomonas campestris pv. vesicatoria, for example, the use of protective formulations such as skim milk mixed with the phage solution has been investigated to ensure that phages applied to foliage do not become inactivated before reaching the pathogenic bacteria (6). In bacterial leaf blight of rice caused by $X$. oryzae pv. oryzae, a phage inhibited the infection from wounded sites only when co-applied with nonpathogenic $X$. campestris, which is nonsuppressive to the disease and can be the host of the phage (3). In the seed sterilization method, seed can be treated at the appropriate time (just before sowing), and phages are not exposed to and not inactivated by ultraviolet rays because germination induction and seedling culture are conducted in the dark or indoors.

Also, unlike spraying of phages in the fields or greenhouses, treating seed with an excess of phages according to the density of pathogenic bacteria in a confined space can be expected to increase the disease control effectiveness. However, it has been reported that the frequency of appearance of phage-resistant bacteria increases when the PFU/CFU ratio is large, as in the case of $X$. campestris pv. pruni and pruniphage (14). Therefore, it will be necessary to conduct a detailed investigation of the appearance of phageresistant bacteria in seed sterilization by phages.

In our small-scale trials, a BGPP-Ar concentration of $10^{7}$ $\mathrm{PFU} / \mathrm{ml}$ or greater was needed to control seedling blight of rice, and a concentration of $10^{5} \mathrm{PFU} / \mathrm{ml}$ completely suppressed seedling rot of rice. In these trials, the water was kept stationary during germination induction. In the medium-scale trials, in which a circulation germinator was used, sufficient efficacy was attained even when the phage concentration was low. With the device, water heated to $30^{\circ} \mathrm{C}$ is circulated by pump up from the immersion tank and is sprayed from above. The high efficacy may be explained by the constant agitation of water, which increases the opportunities for phages to make contact with bacteria.

In conclusion, the use of specific phages against pathogenic bacteria in rice seedlings appears to be effective as a disease control and is environmentally friendly. However, for practical applications, further investigation of phagovars and the appearance of phage-resistant strains will be needed.

\section{Literature Cited}

1. Adachi, N., Ohara, T., and Azegami, K. 2003. Isolation of Burkholderia plantarii as potential biocontrol agents against bacterial seedling blight of rice. (Abstr.) Jpn. J. Phytopathol. 69:286. (In Japanese)

2. Adachi, N., Ohara, T., and Azegami, K. 2004. Occurrence of phage resistant strains of Burkholderia plantaii. (Abstr.) Jpn. J. Phytopathol. 70:67. (In Japanese)

3. Azegami, K., Adachi, N., and Ohara, T. 2003. Phage, when applied with non-pathogenic Xanthomonas campestris, suppresses the occurrence of bacterial leaf blight of rice. (Abstr.) Jpn. J. Phytopathol. 69:286. (In Japanese)

4. Azegami, K., Nishiyama, K., Watanabe, Y., Kadota, I., Ohuchi, A., and Fukuzawa, C. 1987. Pseudomonas plantarii, sp. nov., the causal agent of rice seedling blight. Int. J. Syst. Bacteriol. 37:144-152.

5. Balogh, B., Canteros, B. I., Stall, R. E., and Jones, J.B. 2008. Control of citrus canker and citrus bacterial spot with bacteriophages. Plant Dis. 92:1048-1052.

6. Balogh, B., Jones, J. B., Momol, M. T., Olson, S. M., Obradovic, A., King, P., and Jackson, L. E. 2003. Improved efficacy of newly formulated bacteriophages for management of bacterial spot on tomato. Plant Dis. 87:949-954.

7. Flaherty, J. E., Harbaugh, B. K., Jones, J. B., and Somodi, G. C. 2001. Hmutant bacteriophages as a potential biocontrol of bacterial blight of geranium. HortScience 36:98-100.

8. Flaherty, J. E., Jones, J. B., Harbaugh, B. K., Somodi, G. C., and Jackson, L. E. 2000. Control of bacterial spot on tomato in the greenhouse and field with h-mutant bacteriophages. HortScience 35:882-884.

9. Goto, T., Sato, T., and Kuhara, S. 1976. Distribution of the pathogen of bacterial grain rot of rice on rice plants. (Abstr.) Ann. Phytopathol. Soc. Jpn. 41:113 (In Japanese)

10. Jackson, L. E. 1989. Bacteriophage prevention and control of harmful plant bacteria. U.S. Patent 4,828,999.

11. Kumakura, K., Watanabe, S., Toyoshima, J., Makino, T., Iyozumi, H., Ichikawa, T., and Nagayama, K. 2003. Effect of Trichoderma sp. SKT-1 on suppression of six different seedborne diseases of rice. Jpn. J. Phytopathol. 69:393-402. (In Japanese with English abstract)

12. Lang, J. M., Gent, D. H., and Schwartz. H. F. 2007. Management of Xanthomonas leaf blight of onion with bacteriophages and a plant activator. Plant Dis. 91:871-878.

13. Obradovic, A., Jones, J. B., Momol, M. T., Balogh, B., and Olson, S. 2004. Management of tomato bacterial spot in field by foliar applications of bacteriophages and SAR inducers. Plant Dis. 88:736-740.

14. Randhawa, P. S., and Civerolo, E. L. 1986. Interaction of Xanthomonas campestris pv. pruni with pruniphage and epiphytic bacteria on detached peach leaves. Phytopathology 76:549-553.

15. Tsukamoto, S., Adachi, N., Inoue, Y., Miyagawa, H., and Azegami, K. 2008. Phage typing of Burkholderia plantarii and mutation in phage-sensitivity. (Abstr.) Jpn. J. Phytopathol. 74:251. (In Japanese)

16. Uematsu, T., Yoshimura, D., Nishiyama, K., Ibaraki, T., and Fujii, H. 1976. Occurrence of bacterial seedling rot in nursery flat, caused by grain rot bacterium Pseudomonas glumae. Ann. Phytopathol. Soc. Jpn. 42:310-312. (In Japanese with English abstract)

17. Urakami, T., Ito-Yoshida, C., Araki, H., Kijima, T., Suzuki, K., and Komagata, K. 1994. Transfer of Pseudomonas plantarii and Pseudomonas glumae to Burkholderia as Burkholderia spp. and description of Burkholderia vandii sp. nov. Int. J. Syst. Bacteriol. 44:235-245.

18. Yamashita, T., Eguchi, N., Akanuma, R., and Saito, Y. 2000. Control of seed-borne diseases of rice plants by hot water treatment of rice seeds. 1Control of rice seedling blast and "bakanae" disease by hot water treatment. Annu. Rep. Kanto-Tosan Plant Prot. Soc. 47:7-11. (In Japanese)

19. Yamashita, T., Eguchi, N., Akanuma, R., and Saito, Y. 2000. Control of seed-borne diseases of rice plants by hot water treatment of rice seeds. 3Control of bacterial seeding rot and bacterial seedling blight by hot water treatment. Annu. Rep. Kanto-Tosan Plant Prot. Soc. 47:17-21. (In Japanese)

20. Yamashita, T., Sakai, N., Eguchi, N., Akanuma, R., and Saito, Y. 2000. Control of seed-borne diseases of rice plants by hot water treatment of rice seeds. 2-Effect of hot water treatment on germination of rice plants. Annu. Rep. Kanto-Tosan Plant Prot. Soc. 47:13-16. (In Japanese) 